Review

\title{
Liquid Biopsy Analysis in Clinical Practice: Focus on Lung Cancer
}

\author{
Pasquale Pisapia ${ }^{1}{ }^{1}$, Francesco Pepe ${ }^{1}$, Antonino Iaccarino ${ }^{1}$, Roberta Sgariglia ${ }^{1}$, Mariantonia Nacchio ${ }^{1}$,

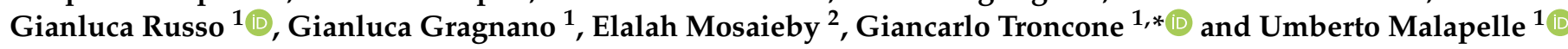 \\ 1 Department of Public Health, University of Naples Federico II, 80131 Naples, Italy; \\ pasquale.pisapia@unina.it (P.P.); francesco.pepe4@unina.it (F.P.); antiaccc@hotmail.com (A.I.); \\ ro.sgariglia@gmail.com (R.S.); nacchiomariantonia92@gmail.com (M.N.); gianlucar93@libero.it (G.R.); \\ gianluca.gragnano@unina.it (G.G.); umberto.malapelle@unina.it (U.M.) \\ 2 Department of Cellular and Molecular Biology, University of Mazandaran, Mazandaran 48175-866, Iran; \\ e.mosaieby67@gmail.com \\ * Correspondence: giancarlo.troncone@unina.it
}

check for updates

Citation: Pisapia, P.; Pepe, F.; Iaccarino, A.; Sgariglia, R.; Nacchio, M.; Russo, G.; Gragnano, G.;

Mosaieby, E.; Troncone, G.; Malapelle, U. Liquid Biopsy Analysis in Clinical Practice: Focus on Lung Cancer. J. Mol. Pathol. 2021, 2, 241-254. https:// doi.org/10.3390/jmp2030021

Academic Editor: Paul

A. VanderLaan

Received: 28 June 2021

Accepted: 14 July 2021

Published: 16 July 2021

Publisher's Note: MDPI stays neutral with regard to jurisdictional claims in published maps and institutional affiliations.

Copyright: (c) 2021 by the authors. Licensee MDPI, Basel, Switzerland. This article is an open access article distributed under the terms and conditions of the Creative Commons Attribution (CC BY) license (https:// creativecommons.org/licenses/by/ $4.0 /)$.

\begin{abstract}
Lung cancer is the leading cause of cancer death worldwide. Despite the emergence of highly effective targeted therapies, up to $30 \%$ of advanced stage non-small cell lung cancer (NSCLC) patients do not undergo tissue molecular testing because of scarce tissue availability. Liquid biopsy, on the other hand, offers these patients a valuable opportunity to receive the best treatment options in a timely manner. Indeed, besides being much faster and less invasive than conventional tissuebased analysis, it can also yield specific information about the genetic make-up and evolution of patients' tumors. However, several issues, including lack of standardized protocols for sample collection, processing, and interpretation, still need to be addressed before liquid biopsy can be fully incorporated into routine oncology practice. Here, we reviewed the most important challenges hindering the implementation of liquid biopsy in oncology practice, as well as the great advantages of this approach for the treatment of NSCLC patients.
\end{abstract}

Keywords: predictive molecular pathology; predictive biomarker; EGFR; molecular oncology; ctDNA

\section{Introduction}

Lung cancer remains the leading cause of cancer death worldwide, despite great advances in diagnostics and treatments [1]. In the era of personalized medicine, obtaining accurate molecular assessments of clinically relevant biomarkers is crucial to ensure advanced stage non-small cell lung cancer (NSCLC) patients the best available treatment [2-5]. However, up to $30 \%$ of these patients do not undergo molecular screening because of insufficient tissue specimens [6]. In this scenario, liquid biopsy may provide a valuable and complementary alternative to tissue biopsy for the assessment of clinically relevant biomarker [7]. (Figure 1) Currently, beyond plasma-derived circulating tumor DNA (ctDNA), several other biological sources are in the process of being approved or under investigation. Among these are urine, cerebro-spinal fluid, blood, saliva, effusions, and analytes, including circulating tumor cells (CTCs), ctRNA, and extracellular vesicles (EVs) (Figure 1) [8-24].

Plasma-derived ctDNA was recently approved by the Food and Drug Administration (FDA) for the assessment of Epidermal Growth Factor Receptor (EGFR) gene molecular status and EGFR exon 20 p.T790M resistance point mutation in advanced stage NSCLC patients [24]. The usefulness of ctDNA in selecting NSCLC patients for first or second generation EGFR tyrosine kinase inhibitors (TKIs) and in identifying EGFR exon 20 p.T790M resistance point mutation has been well documented by our research laboratory and elsewhere $[6,8,9,24]$. Indeed, studies have shown that ctDNA analysis is highly valuable in defining the molecular status of EGFR in advanced stage NSCLC patients who have yet 
to begin treatment, who lack tissue specimens because either unattainable or insufficient, or whose tissue biopsies yield questionable results $[6,8,9,24]$. Likewise, it is useful for identifying patients with the EGFR exon 20 p.T790M resistance point mutation who develop resistance to first or second generation EGFR TKIs and who would most likely benefit from third generation EGFR TKIs $[6,8,9,24]$. Despite the major advantages associated with ctDNA testing, including high patient compliance, low risk of complications, and reliable evaluation tumor molecular heterogeneity [25-27], several technical hurdles must be overcome before it can be fully and successfully adopted in routine oncology care. In particular, our research team and others have shown that its short half-life (about $15 \mathrm{~min}$ ), low blood concentration $(<0.5 \%$ of the total circulating cell free DNA), and the influence associated with the pathological stage of disease, with increasing concentrations in advanced stages of disease may limit its practicability [28-30]. Here, we review the most important challenges and advantages of the adoption of ctDNA in NSCLC patients.

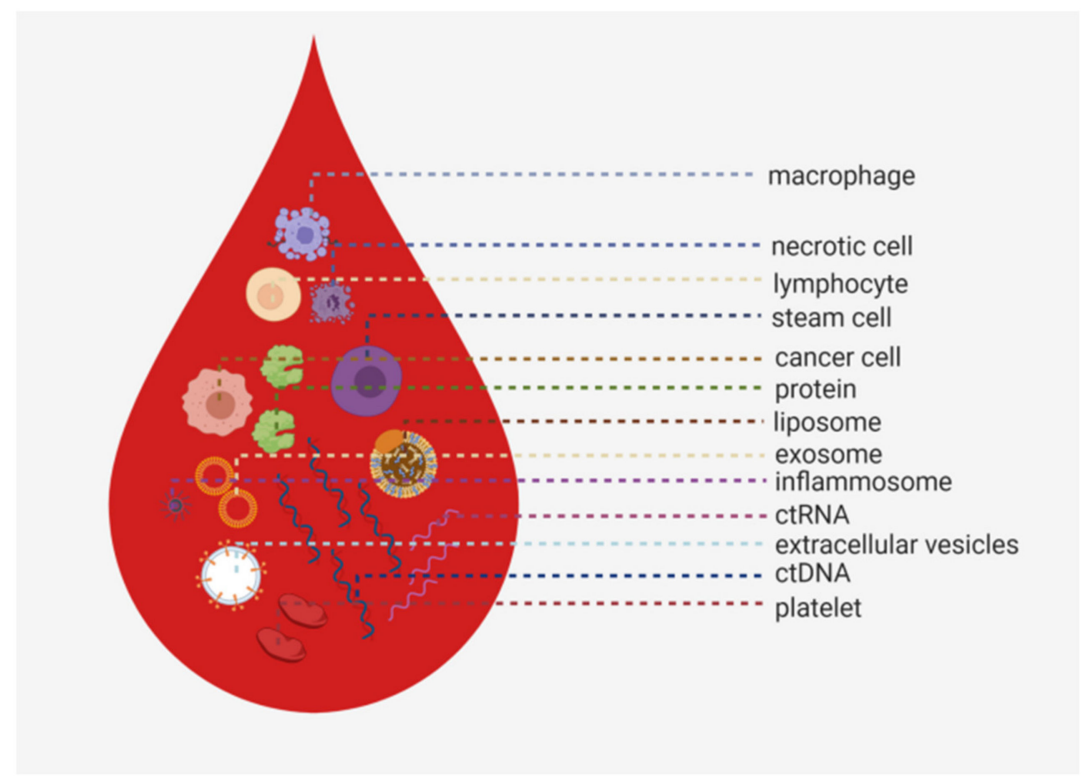

Figure 1. The "cancer world" in a drop. Here we depict the different elements found in liquid biopsy samples of cancer patients.

\section{Pre-Analytical Phase}

Pre-analytical issues should be carefully addressed before liquid biopsy may be fully implemented in routine clinical practice. Not surprisingly, the International Association for the Study of Lung Cancer (IASLC) provides specific recommendations on how to carry out this crucial phase [8]. For instance, for blood sample collection, two different types of tubes are recommended, depending on the time-point at which ctDNA is extracted. The first type is the ethylenediaminetetraacetic acid (K2-EDTA)-containing tubes. The advantages of using these tubes are that EDTA can avoid blood clotting issues arising from delayed blood processing and are cheaper; however, they must be processed more rapidly than preservative tubes $[24,31,32]$. Conversely, preservative tubes, such as PAXgene Blood DNA tubes or Cell-Free DNA BCT tubes, enable clinicians to delay ctDNA extraction and analysis by delaying ctDNA degradation [24,33-35]. Conceivably, ctDNA extraction should be performed within two hours for tubes containing EDTA and three days for tube containing preservative solutions $[8,24]$. Centrifugation of blood samples, which is the subsequent step, is required to remove all non-neoplastic elements within the bloodstream [24,31]. In this regard, different centrifugation protocols have been proposed. For instance, our research laboratory has adopted a two-phase centrifugation procedure involving the same centrifugation speed $(2300 \times g$ for $10 \mathrm{~min}$ at room temperature) $[24,36]$. Sorber et al. also propose a two-phase centrifugation protocol, as recommended by the European Committee for Standardization (CEN), but at different speeds (two-step, $1900 \times \mathrm{g}$ for $10 \mathrm{~min}$ and then 
$16,000 \times g$ for $10 \mathrm{~min}$ at room temperature) [37]. Page et al., instead, propose a three-step centrifugation procedure at various speeds: the first at $1000 \times \mathrm{g}$ for $10 \mathrm{~min}$ at $4{ }^{\circ} \mathrm{C}$, the second at $1000 \times g, 2000 \times g$, or $10,000 \times g$ for $10 \mathrm{~min}$ at $4{ }^{\circ} \mathrm{C}$, and the third, performed after thawing, at $1000 \times g$ for $5 \mathrm{~min}$ at room temperature [38]. On the basis of our experience, we recommend a two-phase centrifugation protocol [8]. Finally, different methodologies for ctDNA extraction have been studied [39]. Among these, magnetic beads-based fully automated protocols have been proposed as the best option [40].

Another major issue hindering the full implementation of ctDNA testing is the lack of consensus in selecting the starting material for ctDNA extraction. For instance, several studies found that plasma is much more sensitive than serum for detecting clinically relevant gene alterations $(65.7 \%$ and $60.5 \%$ reported in the IFUM and LUX-Lung 6 clinical trials compared with $43.1 \%$ and $28.6 \%$ reported in the IPASS and LUX-Lung 3 clinical trials) [30,41-43]. For this reason, the IASLC statement paper recommends adopting plasma samples for ctDNA extraction [8]. However, our laboratory demonstrated a few years ago that it is possible to reach even higher sensitivity, specifically up to $90.5 \%$, when ctDNA is drawn from both plasma and serum [36]. Finally, regarding the last step of the pre-analytical phase, that is, specimen storage, several authors strongly recommend storing unprocessed ctDNA at ultra-cold temperatures $\left(-80^{\circ} \mathrm{C}\right)$ to prevent, or delay ctDNA degradation $[8,44]$.

However, serum and plasma are not the only noninvasive sources for detection of EGFR mutations in NSCLC patients. Indeed, among the many valuable sources of body fluids, much attention has been focused on urine samples most likely because of their abundance and noninvasiveness. Despite these advantages, urine specimens suffer from the high activity of DNA and RNA hydrolyzing enzymes, factors that may hinder retrieval of cell-free tumoral nucleic acids $[45,46]$. Nonetheless, interesting results were obtained by Reckamp et al. in the TIGER-X clinical trial [47]. When the authors compared the results obtained from urine samples (90-100 mL) with those from tissue samples, they observed a sensitivity of $93 \%, 80 \%$, and $83 \%$, and a specificity of $96 \%, 100 \%$, and $94 \%$ for the detection of EGFR exon 20 p.T790M, exon 21 p.L858R and exon 19 deletions, respectively [47].

Taken together, it cannot be denied that although much progress has been made in the field of liquid biopsy, more needs to be done to standardize the handling and storage protocols pertaining to the pre-analytical phase. Indeed, missteps in this delicate phase may compromise the overall outcomes of this valuable approach.

\section{Analytical Phase}

Several different methodologies have been proposed for ctDNA analysis in NSCLC patients. Among these, polymerase chain reaction (PCR)-based platforms are the most popular in clinical trials [30]. In particular, the cobas EGFR Mutation Test v2 (Roche Diagnostics, Basel, Switzerland) was the first to receive FDA approval on the basis of the results of the ENSURE clinical trial [48]. Basically, this approach uses fluorescent labeled probes [30]. However, despite the high specificity for both EGFR-sensitizing mutations [48]. and EGFR exon 20 p.T790M resistant point mutation [49], this approach shows low sensitivity. To overcome this limitation, scientists have developed more sensitive PCR-based approaches. Among these is beads, emulsions, amplification, and magnetics (BEAMing) digital PCR (dPCR). This platform is able to compartmentalize the amplification process in several reaction chambers (water droplets, in oil for digital droplet PCR and BEAMing, and on a solid chip for digital solid PCR) [50-52]. In a meta-analysis by Li et al., digital droplet PCR (ddPCR) and amplification refractory mutation system PCR (ARMSPCR) showed high specificity and sensitivity for EGFR mutation in ctDNA. Of note, ddPCR had a higher sensitivity than ARMS-PCR [53]. Overall, a recent study investigating the various techniques used to analyze ctDNA in liquid biopsy specimens concluded that PCRbased approaches are limited because they can detect only known and well-characterized gene mutations [54]. 
On the other hand, next generation sequencing (NGS) platforms have been shown to be a highly fascinating alternative to PCR-based technologies enabling cytopathologists not only to analyze several biomarkers for different patients simultaneously, but also to identify known and unknown mutations within the adopted panel (wide reference range) [55]. Equally useful has been the adoption of unique molecular identifiers (UMIs). These identifiers, also known as molecular barcodes, can significantly increase testing sensitivity and reduce false negative results $[24,56]$. Other strategies include Tagged-Amplicon deep sequencing (TAm-seq), the Safe-Sequencing System (Safe-SeqS), the CAncer Personalized Profiling by deep sequencing (CAPP-Seq), the Bias-Corrected Targeted NGS and the Multiplex polymerase chain reaction (PCR) combined with the UMI approach $[9,24,57]$. What follows is a brief description of these sequencing platforms.

TAm-seq has shown high sensitivity $(>97 \%)$ for NSCLC EGFR mutations and can accurately monitor disease progression. Noticeably, this approach can identify and quantify even very low frequency alterations (about $2 \%$ ). Generally, it adopts PCR primers designed to cover definite genomic regions. These primers can then be adjusted to amplify specific sections during the pre-amplification step. Nonspecific products are removed by selective re-amplification. Finally, an additional PCR primer is employed to attach adaptors and barcodes [58]. In the years following its development, much effort was spent to improve the sensitivity of this platform for NSCLC EGFR mutations. Notably, less than ten years later, a new version of TAm-seq, called Enhanced Tam-Seq (eTAm-Seq), was designed. As the name suggests, eTAm-Seq considerably much better than the previous approach. Thanks to this new version, cytopathologists are now able to amplify specific genomic regions starting from very low DNA input, obtaining a sensitivity of about $94 \%$. Moreover, they can now correctly identify even EGFR-sensitizing and resistant mutations occurring at very low frequencies $(0.25-0.33 \%)$, thereby providing patients the opportunity to receive targeted treatments [59].

Another valid analytical approach for detecting rare EGFR mutations in NSCLC patients is the Safe-SeqS approach. This approach successfully distinguishes rare mutations from sequencing errors, thereby reducing to a minimum unreliable test results. Indeed, thanks to the use of UMIs [60], it is able to reach an overall sensitivity of 98.0\% [61].

Even more precise is the CAPP-Seq approach. This platform adopts the so called "selector" procedure to detect individual-specific mutations, obtaining a sensitivity of almost $100.0 \%$. Indeed, it can identify gene alterations with allelic frequency as low as $0.02 \%$ [62-64].

One other approach that can maximize on-target reads by minimizing sequencing artifacts is at the basis of the Bias-Corrected Targeted NGS approach. This approach, which uses sequence tags, is able to reach not only a sensitivity and specificity ranging between $88.0 \%$ and $100.0 \%$ for mutations with allelic frequency as low as $0.1 \%$, but it can even reach $100.0 \%$ sensitivity and specificity for mutations with allelic frequency equal to or greater than $0.4 \%$ [65]. Finally, Multiplex-PCR NGS with UMI features a sensitivity of up to $99.0 \%$. Interestingly, the high sensitivity of this approach is based on the association of high throughput PCR amplification, including UMIs, with subsequent ultra-deep sequencing (usually at 25,000 $\times$ coverage) [66].

Despite the efficiency of NGS platforms in reducing to a minimum the chances of skewed test results, they are not devoid of certain limitations. As evidenced by a comparative technical review on the efficiency of NGS platforms in detecting structural variations, the main drawback of these approaches remains the challenging detection of gene rearrangements and interpretation of copy number variants (CNVs) in NSCLC EGFR mutations [67].

\section{Post-Analytical Phase}

Adequately interpreting and reporting genomic alterations is the final step in the molecular testing process. Accordingly, all clinically relevant data should be thoroughly reported to avoid any misinterpretation that might interfere with adequate treatment 
decision making for NSCLC patients. Thus, clear communication between different healthcare figures involved in the management of NSCLC patients is paramount to guarantee optimal care.

Overall, the report should contain all the data necessary to identify each patient, as well as any relevant information regarding the samples originally shipped to the molecular laboratory. In particular, the report should be divided into two main sections. The first part should include all the pre-analytical factors considered for the molecular analysis. The second part, constituting the main body of the report, should comprehensively describe the mutational profile of the analyzed biomarkers $[68,69]$.

In an effort to facilitate accurate interpretation and standardized reporting of molecular data, the Association for Molecular Pathology (AMP), American Society of Clinical Oncology (ASCO), and College of American Pathologists (CAP) proposed a joint consensus recommendation (JCR) based on a 4-tiered system of reporting [67]. Briefly, Tier I contains all clinically relevant and strongly validated variants in cancer development and management; tier II includes potentially oncogenic and actionable variants; tier III covers cancer associated variants of unknown clinical importance; finally tier IV includes known benign or likely benign variants that should not be reported. Moreover, owing to the likely occurrence of false-negative results, the consensus recommends replacing the term "wild type" with "not detected alterations". Lastly, some authors recommend describing all alterations according to the Human Genome Variation Society (HGVS) [70].

In conclusion, these recommendations suggest that laboratory data alone are not enough to guide diagnostic and treatment decision making. Indeed, a careful interpretation of the reported alterations, alongside clear information regarding the molecular tests adopted, including reference ranges, limit of detection (LOD), and NGS run parameters, is paramount to help physicians choose the best treatment options for their patients.

\section{Molecular Tumor Boards}

Collegial discussion within molecular tumor boards (MTBs) may be useful to solve complex cases and improve patients' treatment outcomes [71,72]. Within MTBs, different healthcare specialists involved in the management of cancer patients can discuss the correct management of cancer patients by sharing their previous professional experiences and expertise [71]. In this setting owing to the rapidly increasing complexity of clinically relevant biomarkers, a major role in NSCLC management and other types of advanced stage cancers is played by tools such as the OncoKB, developed by Memorial Sloan Kettering Cancer Center, and the European Society for Medical Oncology Scale for Clinical Actionability of Molecular Targets (ESCAT) [73,74]. Interestingly, these tools, which were originally developed to interpret NGS-based tissue biopsies have proven useful to interpret also in the context of NGS-based liquid biopsies $[75,76]$.

\section{Opportunities}

Cancer interception is a recent concept that identifies the process of thwarting cancer evolution during carcinogenesis before original tumors develop and eventually metastasize [77-82]. In a nutshell, this cancer prevention process in high risk individuals encompasses a series of active interventions including identification and elimination of risk factors associated with carcinogenesis, detection of cancer driver gene mutations, or biomarkers, and implementation of all necessary procedures for early cancer detection, such as screening and early detection programs [77-82]. In the fight against lung cancer development, liquid biopsy may be a useful tool especially in patients with chronic airway inflammation. In this setting, although the correlation between chronic immune system activity and cancer initiation and progression is still under investigation, a recent study suggests that this process may facilitate cancer development [83]. Despite the increasing knowledge about the correlation between chronic obstructive pulmonary diseases (COPDs) and lung cancer initiation and progression, to date low-dose computed tomography (LDCT) with confirmatory invasive tissue biopsy is the only approved screening tool in the diagnostic 
arsenal [84]. In this setting, liquid biopsy may very well be considered a valid non-invasive screening procedure for intercepting lung cancer development in COPDs. Nevertheless, little research has, so far investigated the potential application of liquid biopsy in clinical practice to screen high-risk individuals.

Among the few studies on the use of liquid biopsy as a screening tool for high risk patients is the one by Ilie et al. These authors investigated whether CTCs in the bloodstream of COPD patients without previous radiological evidence of lung cancer could serve as valuable biomarkers for early lung cancer diagnosis. Remarkably, by using the Isolation by Size of Epithelial Tumor cell (ISET) technology, they were able to identify CTCs in five $(3.0 \%)$ out of 168 COPD patients. As expected, all these patients unfortunately developed lung cancer, as evidenced by a CT scan in a follow-up visit. Interestingly, no CTCs were identified in control smoking and non-smoking individuals without COPD [85]. Hoping to confirm these results even further, the same authors carried out a similar study involving a much higher number of high-risk COPD patients $(\mathrm{n}=614)$. Although CTCs were detected only in $11.7 \%$ of patients, it was interesting to see that all of them developed lung cancer [86]. These findings, together with their previous ones, do heighten the predictive role of CTCs in high risk COPD patients and the usefulness of using liquid biopsy as a cancer interception screening tool. Similarly, Romero-Palacios et al. highlighted that the presence of CTCs in the peripheral blood of 17 COPD patients was indicative of early lung cancer development and poor prognosis [87].

Another intriguing field of investigation in the setting of cancer interception and prevention is the predictive role of circulating micro-RNA (miRNA) in lung cancer development. In a large retrospective study, Sozzi et al. demonstrated that a noninvasive plasma miRNA signature classifier (MSC) may not only have a predictive, diagnostic, and prognostic value but also be useful to reduce false-positive detection rates of LDCT scans, thereby determining a significant improvement in lung cancer screening [88]. Similar results have also been reported by Montani et al. in the Continuous Observation of Smoking Subjects (COSMOS) lung cancer screening program study. The results from this large-scale study on the potential application of the miR-Test are noteworthy. The test, administered to 1115 patients, demonstrated an overall accuracy of $74.9 \%$, a sensitivity of $77.8 \%$, and a specificity of $74.8 \%$, suggesting the potential application of this test in clinical practice as a valuable alternative to LDCT or to more invasive procedures [89]. Unfortunately, as far as we know, research on the adoption of ctDNA for cancer interception is still lacking.

Although it still remains to be seen whether ctDNA is useful for cancer interception ctDNA analysis in liquid biopsy may play a crucial role in detecting cancer in asymptomatic individuals, as evidenced in a recent review [90]. Several other studies have indeed substantiated this theory using different types of sequencing approaches. For instance, adopting a super-depth NGS approach, Ye et al. proposed an innovative ctDNA whole mutation score model able to predict malignant solitary pulmonary nodules (SPNs) in $33 \%$ of cases with 100\% specificity-findings suggesting the utility of adopt ctDNA in identifying nodules requiring surgical management [91].

Pursuing the same line of research, Chen et al. were able quantify the presence of ctDNA in $89.7 \%$ of early stage NSCLC patients (IA, IB, and IIA). Noticeably, the detection rate of EGFR mutated cases in ctDNA specimens was similar to that previously detected in tissue specimens (32.8\% and 39.7\% respectively) [92]. Likewise, using a lower denaturation temperature (COLD)-PCR assay coupled with high-resolution melting analysis, Leung et al. very recently confirmed the possibility of detecting mutated ctDNA in the blood of patients with early stage lung cancer, highlighting once again the usefulness of ctDNA as a bloodbased diagnostic test for early detection [93]. This hypothesis was further corroborated by Liang et al. who adopted a high-throughput targeted DNA methylation sequencing approach on ctDNA extracted from plasma samples of solitary pulmonary nodules. The authors demonstrated the feasibility of using ctDNA not only to detect sub-centimeter tumors non-invasively but also to differentiate lung cancers from benign pulmonary nodules [94]. Consistently, Phallen et al. highlighted the usefulness of ctDNA mutation 
analysis by targeted error correction sequencing (TEC-Seq) as a non-invasive screening tool for detecting early stage tumors (stages I and II) in lung cancer patients [95]

Altogether, although much work still needs to be done before liquid biopsy can be incorporated into clinical practice as a noninvasive predictive screening tool for high risk lung cancer patients, corroborating evidence seems to point toward the use of ctDNA, along with CTCs and miRNA, to detect and thwart cancer development in its very early stages.

In a previous review, we amply discussed that liquid biopsy is a valid option for molecular analysis in advanced stage NSCLC patients [6]. Over the past few years, liquid biopsy has indeed enabled us to assess the molecular status of EGFR, Kirsten Rat Sarcoma Viral Oncogene Homolog (KRAS) and V-Raf Murine Sarcoma Viral Oncogene Homolog B $(B R A F)$ in advanced stage NSCLC patients at the basal setting [96-98]. However, beyond the ability to predict the patients' response to targeted therapies, some authors have put forward the idea of using ctDNA analysis as a valuable means for monitoring minimal residual disease in the hope of identifying patients at increased risk of relapse. For example, in the TRACERx study involving the analysis of longitudinal pre-and post-operation samples, the authors saw that the mutations detected within ctDNA were associated with disease recurrence, as later confirmed by computed tomography (CT) [27].

Within this context, liquid biopsy is an excellent alternative to tissue biopsies for several reasons. For instance, it may serve as a useful tool for evaluating tumor genomic heterogeneity, thereby avoiding the common practical issues associated with scarce availability of tissue biopsies in advanced stage NSCLC patients [29,99]. In addition, liquid biopsy can significantly reduce tissue sampling bias generated by distant metastatic lesions, thereby ensuring rapid detection of emerging resistance mechanisms during treatment [29]. In this regard, Chabon et al., who used CAPP-Seq on ctDNA from serial plasma samples of 43 NSCLC patients, succeeded in detecting high intra-patient heterogeneity in $46 \%$ of patients featuring multiple resistance mechanisms [64].

Another interesting scenario is the adoption of liquid biopsy to select patients for immune-checkpoint inhibitors (ICIs). This theory was amply substantiated in the POPLAR and OAK clinical trials, in which a high $(\geq 16$ mut $/ \mathrm{Mb})$ tumor mutational burden (TMB) in blood samples (bTMB) was correlated with a significantly high response rate and progression free survival in advanced stage NSCLC patients [100,101]. A slightly higher cut-off $(\geq 20 \mathrm{mut} / \mathrm{Mb}$ ) has been successfully adopted in the MYSTIC clinical trial. As opposed to conventional chemotherapy, durvalumab plus tremelimumab markedly improved patients' overall survival, progression free survival, and objective response rate [102]

Finally, a wealth of evidence points toward using CTCs or ctRNA to evaluate the expression of Programmed death-ligand 1 (PD-L1) expression [103,104]

Table 1 reports all the studies carried out in this vast field of research.

Table 1. Summary of studies adopting different analytes from blood samples.

\begin{tabular}{ccc}
\hline Authors [Ref] & Analyte & Clinical Setting \\
\hline Ilie et al. [85] & CTC & Cancer interception \\
\hline Marquette et al. [86] & CTC & Cancer interception \\
\hline Romero-Palacios et al. [87] & CTC & Cancer interception \\
\hline Sozzi et al. [88] & miRNA & Cancer interception \\
\hline Montani et al. [89] & miRNA & Cancer interception \\
\hline Ye et al. [91] & ctDNA & Early detection \\
\hline Chen et al. [92] & ctDNA & Early detection \\
\hline Leung et al. [93] & ctDNA & Early detection \\
\hline Liang et al. [94] & ctDNA & Early detection \\
\hline Phallen et al. [95] & ctDNA & Early detection \\
\hline
\end{tabular}


Table 1. Cont.

\begin{tabular}{ccl}
\hline Authors [Ref] & Analyte & Clinical Setting \\
\hline Pisapia et al. [96] & ctDNA & Metastatic setting \\
\hline Nacchio, Sgariglia et al. [97] & ctDNA & Metastatic setting \\
\hline Iaccarino et al. [98] & ctDNA & Metastatic setting \\
\hline Jamal-Hanjani et al. [27] & ctDNA & Metastatic setting \\
\hline Gandara et al. [100] & ctDNA & Metastatic setting \\
\hline Herbst et al. [101] & ctDNA & Metastatic setting \\
\hline Rizvi et al. [102] & ctDNA & Metastatic setting \\
\hline Guibert et al. [103] & CTC & Metastatic setting \\
\hline Raez et al. [104] & ctRNA & Metastatic setting \\
\hline
\end{tabular}

Abbreviations: CTC: circulating tumor cell; ctDNA: circulating tumor DNA; ctRNA: circulating tumor RNA; ref: reference.

\section{Clonal Hematopoiesis of Indeterminate Potential: An Important Issue}

Clonal hematopoiesis of indeterminate potential (CHIP) is associated with the identification of mutations in the bloodstream with unclear pathological significance [105-113]. In brief, CHIP is a condition wherein there is an asymptomatic expansion of blood cells derived from a single hematopoietic stem cell, harboring specific genetic abnormalities in individuals without known hematological malignancies [114]. Commonly, CHIP is correlated with advanced age and involves specific genes, including DNMT3A, ASXL1, and TET2, and, less commonly, TP53, JAK2, NOTCH2, FAT3, EXT2, ERBB4, KRAS, and ARID2) [115-118]. This poses a complex scenario, as it may lead to false-positive results in ctDNA analysis. In Genovese et al.'s study, CHIP-associated mutations were detected in approximately $10 \%$ of subjects older than 65 [114]. Thus, analyzing matched ctDNA and DNA extracted from white blood cell may be a suitable approach to overcome the risk of false positive results by filtering CHIP mutations [119].

\section{Future Directions and Conclusions}

Mounting evidence suggests that liquid biopsy is a valid approach to detect and track molecular changes in both early and advanced stage NSCLC patients. Being easy to use, rapid, cost effective, and, most important, noninvasive, it may very well represent a valuable alternative, or complementary source, to tissue biopsies in routine clinical practice $[120,121]$. Moreover, the clinical utility and reliability of liquid biopsy is clearly reflected by its potential application in future clinical trial designs [122]. In fact, several ongoing clinical trials have already adopted this approach to simplify and accelerate patient selection for targeted treatments. Thus, it would not be surprising if liquid biopsy became the method of choice for tumor genomic profiling after different lines of treatment [123]. Despite these promising considerations, much more needs to be done before this fascinating approach can become a reality in oncology practice. Toward this aim, a concerted effort is needed to standardize the crucial pre-analytical and analytical phases to reduce to a minimum the risk of false results. Equally important, the creation of multidisciplinary molecular tumor boards should become standard of care in various institutions to support treatment-decision making through the exchange of practice-based insights on how to best solve doubtful and complex cases [71,72].

Author Contributions: Conceptualization, P.P., G.T., U.M., Methodology, all authors; Software, all authors; Validation, all authors; Formal Analysis, all authors; Investigation, all authors; Resources, all authors; Data Curation, all authors; Writing-Original Draft Preparation, P.P., G.T., U.M.; Writing-Review \& Editing, all authors; Visualization, all authors; Supervision, G.T., U.M.; Project Administration, G.T., U.M. All authors have read and agreed to the published version of the manuscript. 
Funding: The authors have not declared a specific grant for this review from any funding agency in the public, commercial or not-for-profit sectors.

Institutional Review Board Statement: Not applicable.

Informed Consent Statement: Not applicable.

Data Availability Statement: Data sharing not applicable.

Acknowledgments: We thank Paola Merolla for editing the manuscript.

Conflicts of Interest: Umberto Malapelle has received personal fees (as consultant and/or speaker bureau) from Boehringer Ingelheim, Roche, MSD, Amgen, Thermo Fisher Scientifics, Eli Lilly, Diaceutics, GSK, Merck and AstraZeneca, unrelated to the current work. Giancarlo Troncone reports personal fees (as speaker bureau or advisor) from Roche, MSD, Pfizer and Bayer, unrelated to the current work. The other Authors have nothing to disclose.

\section{References}

1. Siegel, R.L.; Miller, K.D.; Fuchs, H.E.; Jemal, A. Cancer Statistics, 2021. CA Cancer J. Clin. 2021, 71, 7-33. [CrossRef]

2. Matias-Guiu, X.; Stanta, G.; Carneiro, F.; Ryska, A.; Hoefler, G.; Moch, H.; European Society of Pathology (ESP). The leading role of pathology in assessing the somatic molecular alterations of cancer: Position Paper of the European Society of Pathology. Virchows Arch. 2020, 476, 491-497. [CrossRef]

3. Malone, E.R.; Oliva, M.; Sabatini, P.J.B.; Stockley, T.; Siu, L.L. Molecular profiling for precision cancer therapies. Genome Med. 2020, 12, 1-19. [CrossRef] [PubMed]

4. El-Deiry, W.S.; Goldberg, R.M.; Lenz, H.; Shields, A.F.; Gibney, G.T.; Tan, A.R.; Brown, J.; Eisenberg, B.; Heath, E.I.; Phuphanich, S.; et al. The current state of molecular testing in the treatment of patients with solid tumors, 2019. CA Cancer J. Clin. 2019, 69, 305-343. [CrossRef] [PubMed]

5. Conway, A.M.; Mitchell, C.; Kilgour, E.; Brady, G.; Dive, C.; Cook, N. Molecular characterisation and liquid biomarkers in Carcinoma of Unknown Primary (CUP): Taking the 'U' out of 'CUP'. Br. J. Cancer 2019, 120, 141-153. [CrossRef] [PubMed]

6. Pisapia, P.; Malapelle, U.; Troncone, G. Liquid Biopsy and Lung Cancer. Acta Cytol. 2019, 63, 489-496. [CrossRef] [PubMed]

7. Crowley, E.; Di Nicolantonio, F.; Loupakis, F.; Bardelli, A. Liquid biopsy: Monitoring cancer-genetics in the blood. Nat. Rev. Clin. Oncol. 2013, 10, 472-484. [CrossRef]

8. Rolfo, C.; Mack, P.C.; Scagliotti, G.V.; Baas, P.; Barlesi, F.; Bivona, T.G.; Herbst, R.S.; Mok, T.S.; Peled, N.; Pirker, R.; et al. Liquid Biopsy for Advanced Non-Small Cell Lung Cancer (NSCLC): A Statement Paper from the IASLC. J. Thorac. Oncol. 2018, 13, 1248-1268. [CrossRef]

9. Rolfo, C.; Cardona, A.F.; Cristofanilli, M.; Paz-Ares, L.; Diaz-Mochon, J.; Duran, I.; Raez, L.E.; Russo, A.; Lorente, J.A.; Malapelle, U.; et al. Challenges and opportunities of cfDNA analysis implementation in clinical practice: Perspective of the International Society of Liquid Biopsy (ISLB). Crit. Rev. Oncol. 2020, 151, 102978. [CrossRef]

10. Siravegna, G.; Marsoni, S.; Siena, S.; Bardelli, A. Integrating liquid biopsies into the management of cancer. Nat. Rev. Clin. Oncol. 2017, 14, 531-548. [CrossRef]

11. Mader, S.; Pantel, K. Liquid Biopsy: Current Status and Future Perspectives. Oncol. Res. Treat. 2017, 40, 404-408. [CrossRef]

12. Hofman, P.; Popper, H.H. Pathologists and liquid biopsies: To be or not to be? Virchows Arch. 2016, 469, 601-609. [CrossRef]

13. Pennell, N.A.; Arcila, M.E.; Gandara, D.R.; West, H. Biomarker Testing for Patients With Advanced Non-Small Cell Lung Cancer: Real-World Issues and Tough Choices. Am. Soc. Clin. Oncol. Educ. Book 2019, 39, 531-542. [CrossRef]

14. Taverna, S.; Giallombardo, M.; Gil-Bazo, I.; Carreca, A.P.; Castiglia, M.; Chacártegui, J.; Araujo, A.; Alessandro, R.; Pauwels, P.; Peeters, M.; et al. Exosomes isolation and characterization in serum is feasible in non-small cell lung cancer patients: Critical analysis of evidence and potential role in clinical practice. Oncotarget 2016, 7, 28748. [CrossRef] [PubMed]

15. Reclusa, P.; Sirera, R.; Araujo, A.; Giallombardo, M.; Valentino, A.; Sorber, L.; Bazo, I.G.; Pauwels, P.; Rolfo, C. Exosomes genetic cargo in lung cancer: A truly Pandora's box. Transl. Lung Cancer Res. 2016, 5, 483-491. [CrossRef] [PubMed]

16. Wu, X.; Li, J.; Gassa, A.; Buchner, D.; Alakus, H.; Dong, Q.; Ren, N.; Liu, M.; Odenthal, M.; Stippel, D.; et al. Circulating tumor DNA as an emerging liquid biopsy biomarker for early diagnosis and therapeutic monitoring in hepatocellular carcinoma. Int. J. Biol. Sci. 2020, 16, 1551-1562. [CrossRef] [PubMed]

17. Shohdy, K.S.; West, H. (Jack) Circulating Tumor DNA Testing-Liquid Biopsy of a Cancer. JAMA Oncol. 2020, 6, 792. [CrossRef] [PubMed]

18. Neumann, M.H.; Bender, S.; Krahn, T.; Schlange, T. ctDNA and CTCs in Liquid Biopsy-Current Status and Where We Need to Progress. Comput. Struct. Biotechnol. J. 2018, 16, 190-195. [CrossRef]

19. Gorgannezhad, L.; Umer, M.; Islam, N.; Nguyen, N.-T.; Shiddiky, M.J.A. Circulating tumor DNA and liquid biopsy: Opportunities, challenges, and recent advances in detection technologies. Lab. Chip 2018, 18, 1174-1196. [CrossRef]

20. Reclusa, P.; Laes, J.-F.; Malapelle, U.; Valentino, A.; Rocco, D.; Gil-Bazo, I.; Rolfo, C. EML4-ALK translocation identification in RNA exosomal cargo (ExoALK) in NSCLC patients: A novel role for liquid biopsy. Transl. Cancer Res. 2018, 8, S76-S78. [CrossRef] 
21. Best, M.G.; Sol, N.; Kooi, I.; Tannous, J.; Westerman, B.A.; Rustenburg, F.; Schellen, P.; Verschueren, H.; Post, E.; Koster, J.; et al. RNA-Seq of Tumor-Educated Platelets Enables Blood-Based Pan-Cancer, Multiclass, and Molecular Pathway Cancer Diagnostics. Cancer Cell 2015, 28, 666-676. [CrossRef]

22. Best, M.G.; Wesseling, P.; Wurdinger, T. Tumor-Educated Platelets as a Noninvasive Biomarker Source for Cancer Detection and Progression Monitoring. Cancer Res. 2018, 78, 3407-3412. [CrossRef] [PubMed]

23. De Rubis, G.; Rajeev Krishnan, S.; Bebawy, M. Liquid Biopsies in Cancer Diagnosis, Monitoring, and Prognosis. Trends Pharm. Sci. 2019, 40, 172-186. [CrossRef] [PubMed]

24. Pisapia, P.; Costa, J.L.; Pepe, F.; Russo, G.; Gragnano, G.; Russo, A.; Iaccarino, A.; de Miguel-Perez, D.; Serrano, M.J.; Denninghoff, V.; et al. Next generation sequencing for liquid biopsy based testing in non-small cell lung cancer in 2021. Crit. Rev. Oncol. 2021, 161, 103311. [CrossRef]

25. Sacher, A.G.; Komatsubara, K.M.; Oxnard, G.R. Application of Plasma Genotyping Technologies in Non-Small Cell Lung Cancer: A Practical Review. J. Thorac. Oncol. 2017, 12, 1344-1356. [CrossRef] [PubMed]

26. Bai, Y.; Zhao, H. Liquid biopsy in tumors: Opportunities and challenges. Ann. Transl. Med. 2018, 6, S89. [CrossRef]

27. Jamal-Hanjani, M.; Wilson, G.; McGranahan, N.; Birkbak, N.J.; Watkins, T.B.K.; Veeriah, S.; Shafi, S.; Johnson, D.H.; Mitter, R.; Rosenthal, R.; et al. Tracking the Evolution of Non-Small-Cell Lung Cancer. N. Engl. J. Med. 2017, 376, 2109-2121. [CrossRef] [PubMed]

28. Malapelle, U.; Pisapia, P.; Rocco, D.; Smeraglio, R.; Di Spirito, M.; Bellevicine, C.; Troncone, G. Next generation sequencing techniques in liquid biopsy: Focus on non-small cell lung cancer patients. Transl. Lung Cancer Res. 2016, 5, 505-510. [CrossRef]

29. Siravegna, G.; Mussolin, B.; Venesio, T.; Marsoni, S.; Seoane, J.; Dive, C.; Papadopoulos, N.; Kopetz, S.; Corcoran, R.; Siu, L.; et al. How liquid biopsies can change clinical practice in oncology. Ann. Oncol. 2019, 30, 1580-1590. [CrossRef]

30. Malapelle, U.; Sirera, R.; Jantus-Lewintre, E.; Reclusa, P.; Calabuig-Fariñas, S.; Blasco, A.; Pisapia, P.; Rolfo, C.; Camps, C. Profile of the Roche cobas ${ }^{\circledR}$ EGFR mutation test v2 for non-small cell lung cancer. Expert Rev. Mol. Diagn. 2017, 17, 209-215. [CrossRef]

31. Lam, N.Y.; Rainer, T.; Chiu, R.W.; Lo, Y.D. EDTA Is a Better Anticoagulant than Heparin or Citrate for Delayed Blood Processing for Plasma DNA Analysis. Clin. Chem. 2004, 50, 256-257. [CrossRef]

32. Sherwood, J.L.; Corcoran, C.; Brown, H.; Sharpe, A.D.; Musilova, M.; Kohlmann, A. Optimised Pre-Analytical Methods Improve KRAS Mutation Detection in Circulating Tumour DNA (ctDNA) from Patients with Non-Small Cell Lung Cancer (NSCLC). PLoS ONE 2016, 11, e0150197. [CrossRef]

33. Medina Diaz, I.; Nocon, A.; Mehnert, D.H.; Fredebohm, J.; Diehl, F.; Holtrup, F. Performance of Streck cfDNA Blood Collection Tubes for Liquid Biopsy Testing. PLoS ONE 2016, 11, e0166354. [CrossRef]

34. Rothwell, D.G.; Smith, N.; Morris, D.; Leong, H.S.; Li, Y.; Hollebecque, A.; Ayub, M.; Carter, L.; Antonello, J.; Franklin, L.; et al. Genetic profiling of tumours using both circulating free DNA and circulating tumour cells isolated from the same preserved whole blood sample. Mol. Oncol. 2015, 10, 566-574. [CrossRef] [PubMed]

35. Schmidt, B.; Reinicke, D.; Reindl, I.; Bork, I.; Wollschläger, B.; Lambrecht, N.; Fleischhacker, M. Liquid biopsy-Performance of the PAXgene ${ }^{\circledR}$ Blood ccfDNA Tubes for the isolation and characterization of cell-free plasma DNA from tumor patients. Clin. Chim. Acta 2017, 469, 94-98. [CrossRef]

36. Malapelle, U.; Mayo de-Las-Casas, C.; Rocco, D.; Garzon, M.; Pisapia, P.; Jordana-Ariza, N.; Russo, M.; Sgariglia, R.; De Luca, C.; Pepe, F.; et al. Development of a gene panel for next-generation sequencing of clinically relevant mutations in cell-free DNA from cancer patients. Br. J. Cancer 2017, 116, 802-810. [CrossRef] [PubMed]

37. Sorber, L.; Zwaenepoel, K.; Jacobs, J.; De Winne, K.; Goethals, S.; Reclusa, P.; Van Casteren, K.; Augustus, E.; Lardon, F.; Roeyen, G.; et al. Circulating Cell-Free DNA and RNA Analysis as Liquid Biopsy: Optimal Centrifugation Protocol. Cancers 2019, 11, 458. [CrossRef] [PubMed]

38. Page, K.; Guttery, D.S.; Zahra, N.; Primrose, L.; Elshaw, S.R.; Pringle, J.H.; Blighe, K.; Marchese, S.D.; Hills, A.; Woodley, L.; et al. Influence of plasma processing on recovery and analysis of circulating nucleic acids. PLoS ONE 2013, 8, e77963. [CrossRef]

39. Mauger, F.; Dulary, C.; Daviaud, C.; Deleuze, J.-F.; Tost, J. Comprehensive evaluation of methods to isolate, quantify, and characterize circulating cell-free DNA from small volumes of plasma. Anal. Bioanal. Chem. 2015, 407, 6873-6878. [CrossRef]

40. Sorber, L.; Zwaenepoel, K.; Deschoolmeester, V.; Roeyen, G.; Lardon, F.; Rolfo, C.; Pauwels, P. A Comparison of Cell-Free DNA Isolation Kits: Isolation and Quantification of Cell-Free DNA in Plasma. J. Mol. Diagn. 2017, 19, 162-168. [CrossRef]

41. Mok, T.S.; Wu, Y.-L.; Thongprasert, S.; Yang, C.-H.; Chu, D.-T.; Saijo, N.; Sunpaweravong, P.; Han, B.; Margono, B.; Ichinose, Y.; et al. Gefitinib or Carboplatin-Paclitaxel in Pulmonary Adenocarcinoma. N. Engl. J. Med. 2009, 361, 947-957. [CrossRef]

42. Douillard, J.-Y.; Ostoros, G.; Cobo, M.; Ciuleanu, T.E.; McCormack, R.; Webster, A.R.; Milenkova, T. First-line gefitinib in Caucasian EGFR mutation-positive NSCLC patients: A phase-IV, open-label, single-arm study. Br. J. Cancer 2014, 110, 55-62. [CrossRef]

43. Yang, J.C.-H.; Wu, Y.; Schuler, M.; Sebastian, M.; Popat, S.; Yamamoto, N.; Zhou, C.; Hu, C.-P.; O’Byrne, K.; Feng, J.; et al. Afatinib versus cisplatin-based chemotherapy for EGFR mutation-positive lung adenocarcinoma (LUX-Lung 3 and LUX-Lung 6): Analysis of overall survival data from two randomised, phase 3 trials. Lancet Oncol. 2015, 16, 141-151. [CrossRef]

44. Remon, J.; García-Campelo, R.; de Álava, E.; Vera, R.; Rodríguez-Peralto, J.L.; Rodríguez-Lescure, Á.; Bellosillo, B.; Garrido, P.; Rojo, F.; Álvarez-Alegret, R. Liquid biopsy in oncology: A consensus statement of the Spanish Society of Pathology and the Spanish Society of Medical Oncology. Clin. Transl. Oncol. 2020, 22, 823-834. [CrossRef]

45. Nadano, D.; Yasuda, T.; Kishi, K. Measurement of deoxyribonuclease I activity in human tissues and body fluids by a single radial enzyme-diffusion method. Clin. Chem. 1993, 39, 448-452. [CrossRef] [PubMed] 
46. Mall, C.; Rocke, D.M.; Durbin-Johnson, B.; Weiss, R.H. Stability of miRNA in human urine supports its biomarker potential. Biomark. Med. 2013, 7, 623-631. [CrossRef] [PubMed]

47. Reckamp, K.L.; Melnikova, V.O.; Karlovich, C.; Sequist, L.V.; Camidge, D.R.; Wakelee, H.; Perol, M.; Oxnard, G.R.; Kosco, K.; Croucher, P.; et al. A Highly Sensitive and Quantitative Test Platform for Detection of NSCLC EGFR Mutations in Urine and Plasma. J. Thorac. Oncol. 2016, 11, 1690-1700. [CrossRef] [PubMed]

48. Wu, Y.-L.; Zhou, C.; Liam, C.-K.; Wu, G.; Liu, X.; Zhong, Z.; Lu, S.; Cheng, Y.; Han, B.; Chen, L.; et al. First-line erlotinib versus gemcitabine/cisplatin in patients with advanced EGFR mutation-positive non-small-cell lung cancer: Analyses from the phase III, randomized, open-label, ENSURE study. Ann. Oncol. 2015, 26, 1883-1889. [CrossRef]

49. Mok, T.S.; Wu, Y.-L.; Ahn, M.-J.; Garassino, M.C.; Kim, H.R.; Ramalingam, S.S.; Shepherd, F.A.; He, Y.; Akamatsu, H.; Theelen, W.S.; et al. AURA3 Investigators. Osimertinib or Platinum-Pemetrexed in EGFR T790M-Positive Lung Cancer. N. Engl. J. Med. 2017, 376, 629-640. [CrossRef] [PubMed]

50. O'Leary, B.; Hrebien, S.; Beaney, M.; Fribbens, C.; Garcia-Murillas, I.; Jiang, J.; Li, Y.; Bartlett, C.H.; Andre, F.; Loibl, S.; et al. Comparison of BEAMing and Droplet Digital PCR for Circulating Tumor DNA Analysis. Clin. Chem. 2019, 65, 1405-1413. [CrossRef] [PubMed]

51. Malapelle, U.; De Luca, C.; Vigliar, E.; Ambrosio, F.; Rocco, D.; Pisapia, P.; Bellevicine, C.; Troncone, G. EGFR mutation detection on routine cytological smears of non-small cell lung cancer by digital PCR: A validation study. J. Clin. Pathol. 2016, 69, 454-457. [CrossRef] [PubMed]

52. Oxnard, G.R.; Thress, K.S.; Alden, R.S.; Lawrance, R.; Paweletz, C.P.; Cantarini, M.; Yang, J.C.-H.; Barrett, J.C.; Jänne, P.A. Association Between Plasma Genotyping and Outcomes of Treatment With Osimertinib (AZD9291) in Advanced Non-Small-Cell Lung Cancer. J. Clin. Oncol. 2016, 34, 3375-3382. [CrossRef] [PubMed]

53. Li, C.; He, Q.; Liang, H.; Cheng, B.; Li, J.; Xiong, S.; Zhao, Y.; Guo, M.; Liu, Z.; He, J.; et al. Diagnostic Accuracy of Droplet Digital PCR and Amplification Refractory Mutation System PCR for Detecting EGFR Mutation in Cell-Free DNA of Lung Cancer: A Meta-Analysis. Front. Oncol. 2020, 10, 290. [CrossRef] [PubMed]

54. Elazezy, M.; Joosse, S.A. Techniques of using circulating tumor DNA as a liquid biopsy component in cancer management. Comput. Struct. Biotechnol. J. 2018, 16, 370-378. [CrossRef] [PubMed]

55. Vigliar, E.; Malapelle, U.; de Luca, C.; Bellevicine, C.; Troncone, G. Challenges and opportunities of next-generation sequencing: A cytopathologist's perspective. Cytopathology 2015, 26, 271-283. [CrossRef]

56. Kinde, I.; Wu, J.; Papadopoulos, N.; Kinzler, K.W.; Vogelstein, B. Detection and quantification of rare mutations with massively parallel sequencing. Proc. Natl. Acad. Sci. USA 2011, 108, 9530-9535. [CrossRef]

57. Chen, M.; Zhao, H. Next-generation sequencing in liquid biopsy: Cancer screening and early detection. Hum. Genom. 2019, 13, 34. [CrossRef] [PubMed]

58. Forshew, T.; Murtaza, M.; Parkinson, C.; Gale, D.; Tsui, D.W.Y.; Kaper, F.; Dawson, S.-J.; Piskorz, A.M.; Jimenez-Linan, M.; Bentley, D.; et al. Noninvasive Identification and Monitoring of Cancer Mutations by Targeted Deep Sequencing of Plasma DNA. Sci. Transl. Med. 2012, 4, 136ra68. [CrossRef]

59. Gale, D.; Lawson, A.R.J.; Howarth, K.; Madi, M.; Durham, B.; Smalley, S.; Calaway, J.; Blais, S.; Jones, G.; Clark, J.; et al. Development of a highly sensitive liquid biopsy platform to detect clinically-relevant cancer mutations at low allele fractions in cell-free DNA. PLoS ONE 2018, 13, e0194630.

60. Esposito Abate, R.; Frezzetti, D.; Maiello, M.R.; Gallo, M.; Camerlingo, R.; De Luca, A.; De Cecio, R.; Morabito, A.; Normanno, N. Next Generation Sequencing-Based Profiling of Cell Free DNA in Patients with Advanced Non-Small Cell Lung Cancer: Advantages and Pitfalls. Cancers 2020, 12, 3804. [CrossRef]

61. Tie, J.; Kinde, I.; Wang, Y.; Wong, H.L.; Roebert, J.; Christie, M.; Tacey, M.; Wong, R.; Singh, M.; Karapetis, C.; et al. Circulating tumor DNA as an early marker of therapeutic response in patients with metastatic colorectal cancer. Ann. Oncol. 2015, 26, 1715-1722. [CrossRef]

62. Newman, A.; Bratman, S.; To, J.; Wynne, J.F.; Eclov, N.C.W.; Modlin, L.A.; Liu, C.L.; Neal, J.W.; Wakelee, H.A.; Merritt, R.E.; et al. An ultrasensitive method for quantitating circulating tumor DNA with broad patient coverage. Nat. Med. 2014, 20, 548-554. [CrossRef]

63. Newman, A.; Lovejoy, A.F.; Klass, D.M.; Kurtz, D.; Chabon, J.J.; Scherer, F.; Stehr, H.; Liu, C.L.; Bratman, S.; Say, C.; et al. Integrated digital error suppression for improved detection of circulating tumor DNA. Nat. Biotechnol. 2016, 34, 547-555. [CrossRef]

64. Chabon, J.J.; Simmons, A.D.; Lovejoy, A.F.; Esfahani, M.S.; Newman, A.M.; Haringsma, H.J.; Kurtz, D.M.; Stehr, H.; Scherer, F.; Karlovich, C.A.; et al. Correction: Corrigendum: Circulating tumour DNA profiling reveals heterogeneity of EGFR inhibitor resistance mechanisms in lung cancer patients. Nat. Commun. 2016, 7, 13513. [CrossRef]

65. Paweletz, C.P.; Sacher, A.; Raymond, C.K.; Alden, R.S.; O'Connell, A.; Mach, S.L.; Kuang, Y.; Gandhi, L.; Kirschmeier, P.; English, J.M.; et al. Bias-Corrected Targeted Next-Generation Sequencing for Rapid, Multiplexed Detection of Actionable Alterations in Cell-Free DNA from Advanced Lung Cancer Patients. Clin. Cancer Res. 2016, 22, 915-922. [CrossRef] [PubMed]

66. Abbosh, C.; Birkbak, N.J.; Wilson, G.A.; Jamal-Hanjani, M.; Constantin, T.; Salari, R.; Le Quesne, J.; Moore, D.A.; Veeriah, S.; Rosenthal, R.; et al. TRACERx consortium; PEACE consortium, Swanton C. Phylogenetic ctDNA analysis depicts early-stage lung cancer evolution. Nature 2017, 545, 446-451. [CrossRef]

67. Guan, P.; Sung, W.K. Structural variation detection using next-generation sequencing data: A comparative technical review. Methods 2016, 102, 36-49. [CrossRef] 
68. Cree, I.A.; Deans, Z.; Ligtenberg, M.J.; Normanno, N.; Edsjö, A.; Rouleau, E.; Solé, F.; Thunnissen, E.; Timens, W.; Schuuring, E.; et al. European Society of Pathology Task Force on Quality Assurance in Molecular Pathology; Royal College of Pathologists. Guidance for laboratories performing molecular pathology for cancer patients. J. Clin. Pathol. 2014, 67, 923-931. [CrossRef] [PubMed]

69. Li, M.M.; Datto, M.; Duncavage, E.J.; Kulkarni, S.; Lindeman, N.I.; Roy, S.; Tsimberidou, A.M.; Vnencak-Jones, C.L.; Wolff, D.J.; Younes, A.; et al. Standards and Guidelines for the Interpretation and Reporting of Sequence Variants in Cancer: A Joint Consensus Recommendation of the Association for Molecular Pathology, American Society of Clinical Oncology, and College of American Pathologists. J. Mol. Diagn. 2017, 19, 4-23. [CrossRef]

70. den Dunnen, J.T.; Dalgleish, R.; Maglott, D.R.; Hart, R.K.; Greenblatt, M.S.; McGowan-Jordan, J.; Roux, A.F.; Smith, T.; Antonarakis, S.E.; Taschner, P.E. HGVS Recommendations for the Description of Sequence Variants: 2016 Update. Hum. Mutat. 2016, 37, 564-569. [CrossRef] [PubMed]

71. Kato, S.; Kim, K.H.; Lim, H.J.; Boichard, A.; Nikanjam, M.; Weihe, E.; Kuo, D.J.; Eskander, R.N.; Goodman, A.; Galanina, $\mathrm{N}$; ; et al. Real-world data from a molecular tumor board demonstrates improved outcomes with a precision $\mathrm{N}$-of-One strategy. Nat. Commun. 2020, 11, 1-9. [CrossRef]

72. Koopman, B.; van der Wekken, A.J.; ter Elst, A.; Hiltermann, T.J.N.; Vilacha, J.F.; Groves, M.R.; Berg, A.V.D.; Hiddinga, B.I.; Hijmering-Kappelle, L.B.M.; Stigt, J.A.; et al. Relevance and Effectiveness of Molecular Tumor Board Recommendations for Patients With Non-Small-Cell Lung Cancer With Rare or Complex Mutational Profiles. JCO Precis. Oncol. 2020, 4, 393-410. [CrossRef]

73. Leichsenring, J.; Horak, P.; Kreutzfeldt, S.; Heining, C.; Christopoulos, P.; Volckmar, A.; Neumann, O.; Kirchner, M.; Ploeger, C.; Budczies, J.; et al. Variant classification in precision oncology. Int. J. Cancer 2019, 145, 2996-3010. [CrossRef]

74. Chakravarty, D.; Gao, J.; Phillips, S.M.; Kundra, R.; Zhang, H.; Wang, J.; Rudolph, J.E.; Yaeger, R.; Soumerai, T.; Nissan, M.H.; et al. OncoKB: A Precision Oncology Knowledge Base. JCO Precis. Oncol. 2017, 2017, 1-16. [CrossRef]

75. Russo, A.; McCusker, M.; Chen, J.; Scilla, K.; Mehra, R.; Gittens, A.; Rolfo, C.O. 01 Challenges of Interpreting NGS Liquid Biopsy (LB) Results in Advanced NSCLC: Are ESCAT and OncoKB Scales Reliable? J. Thorac. Oncol. 2019, 14, S1152. [CrossRef]

76. Mezquita, L.; Planchard, D.; Dorta Suarez, M.; Aldea, M.; Naltet, C.; Lamberts, V.; Grecea, M.; Martin-Romano, P.; de Kievit, F.; Jovelet, C.; et al. 364O Clinical utility of ctDNA genomic alterations (GA) based on ESMO scale for clinical actionability of molecular targets (ESCAT) in advanced NSCLC. Ann. Oncol. 2019, 30, ix122-ix130. [CrossRef]

77. Serrano, M.J.; Garrido-Navas, M.C.; Mochon, J.J.D.; Cristofanilli, M.; Gil-Bazo, I.; Pauwels, P.; Malapelle, U.; Russo, A.; Lorente, J.A.; Ruiz-Rodriguez, A.J.; et al. Precision Prevention and Cancer Interception: The New Challenges of Liquid Biopsy. Cancer Discov. 2020, 10, 1635-1644. [CrossRef]

78. Blackburn, E.H. Cancer interception. Cancer Prev. Res. 2011, 4, 787-792. [CrossRef] [PubMed]

79. Beane-Ebel, J.; Campbell, J.D.; Lel, J.; Vick, J.; Spira, A. Genomic approaches to accelerate cancer interception. Lancet Oncol. 2017, 18, e494-e502. [CrossRef]

80. Spira, A.; Yurgelun, M.B.; Alexandrov, L.B.; Rao, A.; Bejar, R.; Polyak, K.; Giannakis, M.; Shilatifard, A.; Finn, O.J.; Dhodapkar, M.V.; et al. Precancer Atlas to Drive Precision Prevention Trials. Cancer Res. 2017, 77, 1510-1541. [CrossRef]

81. Golemis, E.; Scheet, P.; Beck, T.N.; Scolnick, E.M.; Hunter, D.J.; Hawk, E.; Hopkins, N. Molecular mechanisms of the preventable causes of cancer in the United States. Genes Dev. 2018, 32, 868-902. [CrossRef] [PubMed]

82. Albini, A.; DeCensi, A.; Cavalli, F.; Costa, A. Cancer Prevention and Interception: A New Era for Chemopreventive Approaches. Clin. Cancer Res. 2016, 22, 4322-4327. [CrossRef] [PubMed]

83. McGrath, J.J.C.; Stampfli, M.R. The immune system as a victim and aggressor in chronic obstructive pulmonary disease. J. Thorac. Dis. 2018, 10, S2011-S2017. [CrossRef] [PubMed]

84. Oudkerk, M.; Devaraj, A.; Vliegenthart, R.; Henzler, T.; Prosch, H.; Heussel, C.P.; Bastarrika, G.; Sverzellati, N.; Mascalchi, M.; Delorme, S.; et al. European position statement on lung cancer screening. Lancet Oncol. 2017, 18, e754-e766. [CrossRef]

85. Ilie, M.; Hofman, V.; Long, E.; Selva, E.; Vignaud, J.-M.; Padovani, B.; Mouroux, J.; Marquette, C.H.; Hofman, P. "Sentinel" Circulating Tumor Cells Allow Early Diagnosis of Lung Cancer in Patients with Chronic Obstructive Pulmonary Disease. PLoS ONE 2014, 9, e111597. [CrossRef] [PubMed]

86. Marquette, C.-H.; Boutros, J.; Benzaquen, J.; Ferreira, M.; Pastre, J.; Pison, C.; Padovani, B.; Bettayeb, F.; Fallet, V.; Guibert, N.; et al. Circulating tumour cells as a potential biomarker for lung cancer screening: A prospective cohort study. Lancet Respir. Med. 2020, 8, 709-716. [CrossRef]

87. Romero-Palacios, P.J.; Alcázar-Navarrete, B.; Mochón, J.J.D.; de Miguel-Pérez, D.; Hidalgo, J.L.L.; Garrido-Navas, M.D.C.; Valenzuela, F.Q.; Lorente, J.A.; Serrano, M.J. Liquid biopsy beyond of cancer: Circulating pulmonary cells as biomarkers of COPD aggressivity. Crit. Rev. Oncol. 2019, 136, 31-36. [CrossRef]

88. Sozzi, G.; Boeri, M.; Rossi, M.; Verri, C.; Suatoni, P.; Bravi, F.; Roz, L.; Conte, D.; Grassi, M.; Sverzellati, N.; et al. Clinical Utility of a Plasma-Based miRNA Signature Classifier Within Computed Tomography Lung Cancer Screening: A Correlative MILD Trial Study. J. Clin. Oncol. 2014, 32, 768-773. [CrossRef]

89. Montani, F.; Marzi, M.J.; Dezi, F.; Dama, E.; Carletti, R.M.; Bonizzi, G.; Bertolotti, R.; Bellomi, M.; Rampinelli, C.; Maisonneuve, P.; et al. miR-Test: A blood test for lung cancer early detection. J. Natl. Cancer Inst. 2015, 107, djv063. [CrossRef]

90. Russo, A.; Pérez, D.D.M.; Gunasekaran, M.; Scilla, K.; Lapidus, R.; Cooper, B.; Mehra, R.; Adamo, V.; Malapelle, U.; Rolfo, C. Liquid biopsy tracking of lung tumor evolutions over time. Expert Rev. Mol. Diagn. 2019, 19, 1099-1108. [CrossRef] 
91. Ye, M.; Li, S.; Huang, W.; Wang, C.; Liu, L.; Liu, J.; Liu, J.; Pan, H.; Deng, Q.; Tang, H.; et al. Comprehensive targeted super-deep next generation sequencing enhances differential diagnosis of solitary pulmonary nodules. J. Thorac. Dis. 2018, 10, S820-S829. [CrossRef] [PubMed]

92. Chen, K.-Z.; Lou, F.; Yang, F.; Zhang, J.-B.; Ye, H.; Chen, W.; Guan, T.; Zhao, M.-Y.; Su, X.-X.; Shi, R.; et al. Circulating Tumor DNA Detection in Early-Stage Non-Small Cell Lung Cancer Patients by Targeted Sequencing. Sci. Rep. 2016, 6, 31985. [CrossRef]

93. Leung, M.; Freidin, M.B.; Freydin, M.; Bsc, C.V.C.; De Sousa, P.; Barbosa, M.T.; Nicholson, A.G.; Lim, E. Blood-based circulating tumor DNA mutations as a diagnostic and prognostic biomarker for lung cancer. Cancer 2020, 126, 1804-1809. [CrossRef] [PubMed]

94. Liang, W.; Zhao, Y.; Huang, W.; Gao, Y.; Xu, W.; Tao, J.; Yang, M.; Li, L.; Ping, W.; Shen, H.; et al. Non-invasive diagnosis of early-stage lung cancer using high-throughput targeted DNA methylation sequencing of circulating tumor DNA (ctDNA). Theranostics 2019, 9, 2056-2070. [CrossRef] [PubMed]

95. Phallen, J.; Sausen, M.; Adleff, V.; Leal, A.; Hruban, C.; White, J.; Anagnostou, V.; Fiksel, J.; Cristiano, S.; Papp, E.; et al. Direct detection of early-stage cancers using circulating tumor DNA. Sci. Transl. Med. 2017, 9, eaan2415. [CrossRef] [PubMed]

96. Pisapia, P.; Pepe, F.; Smeraglio, R.; Russo, M.; Rocco, D.; Sgariglia, R.; Nacchio, M.; De Luca, C.; Vigliar, E.; Bellevicine, C.; et al. Cell free DNA analysis by $\mathrm{SiRe}{ }^{\circledR}$ next generation sequencing panel in non small cell lung cancer patients: Focus on basal setting. J. Thorac. Dis. 2017, 9, S1383-S1390. [CrossRef]

97. Nacchio, M.; Sgariglia, R.; Gristina, V.; Pisapia, P.; Pepe, F.; De Luca, C.; Migliatico, I.; Clery, E.; Greco, L.; Vigliar, E.; et al. KRAS mutations testing in non-small cell lung cancer: The role of Liquid biopsy in the basal setting. J. Thorac. Dis. 2020, 12, 3836-3843. [CrossRef] [PubMed]

98. Iaccarino, A.; Pisapia, P.; Pepe, F.; Sgariglia, R.; Nacchio, M.; Russo, G.; Gragnano, G.; De Luca, C.; Troncone, G.; Malapelle, U. Liquid biopsy for BRAF mutations testing in non-small cell lung cancer: A retrospective study. J. Clin. Pathol. 2020. [CrossRef]

99. Passaro, A.; Malapelle, U.; Del Re, M.; Attili, I.; Russo, A.; Guerini-Rocco, E.; Fumagalli, C.; Pisapia, P.; Pepe, F.; De Luca, C.; et al. Understanding EGFR heterogeneity in lung cancer. ESMO Open 2020, 5, e000919. [CrossRef]

100. Gandara, D.R.; Paul, S.M.; Kowanetz, M.; Schleifman, E.; Zou, W.; Li, Y.; Rittmeyer, A.; Fehrenbacher, L.; Otto, G.; Malboeuf C.; et al. Blood-based tumor mutational burden as a predictor of clinical benefit in non-small-cell lung cancer patients treated with atezolizumab. Nat. Med. 2018, 24, 1441-1448. [CrossRef]

101. Herbst, R.S.; Giaccone, G.; De Marinis, F.; Reinmuth, N.; Vergnenegre, A.; Barrios, C.H.; Morise, M.; Felip, E.; Andric, Z.; Geater, S.; et al. Atezolizumab for First-Line Treatment of PD-L1-Selected Patients with NSCLC. N. Engl. J. Med. 2020, 383, 1328-1339. [CrossRef] [PubMed]

102. Rizvi, N.A.; Cho, B.C.; Reinmuth, N.; Lee, K.H.; Luft, A.; Ahn, M.J.; van den Heuvel, M.M.; Cobo, M.; Vicente, D.; Smolin, A.; et al. MYSTIC Investigators. Durvalumab With or Without Tremelimumab vs Standard Chemotherapy in First-line Treatment of Metastatic Non-Small Cell Lung Cancer: The MYSTIC Phase 3 Randomized Clinical Trial. JAMA Oncol. 2020, 6, 661-674. [CrossRef]

103. Guibert, N.; Delaunay, M.; Lusque, A.; Boubekeur, N.; Rouquette, I.; Clermont, E.; Mourlanette, J.; Gouin, S.; Dormoy, I.; Favre, G.; et al. PD-L1 expression in circulating tumor cells of advanced non-small cell lung cancer patients treated with nivolumab. Lung Cancer 2018, 120, 108-112. [CrossRef]

104. Raez, L.; Usher, J.; Sumarriva, D.; Danenberg, K.; Hunis, B.; Jaimes, Y.; Domingo, G. PD2.01 PD-L1 and Other Potential Predictive Biomarkers Measured in Plasma by RT-PCR in cfRNA and cfDNA to Monitor Clinical Responses in Metastatic Lung Cancer Patients. J. Thorac. Oncol. 2019, 14, S1170. [CrossRef]

105. Bick, A.G.; Weinstock, J.S.; Nandakumar, S.K.; Fulco, C.P.; Bao, E.L.; Zekavat, S.M.; Szeto, M.D.; Liao, X.; Leventhal, M.J.; Nasser, J.; et al. Inherited causes of clonal haematopoiesis in 97,691 whole genomes. Nature. 2020, 586, 763-768. [CrossRef] [PubMed]

106. Challen, G.; A Goodell, M. Clonal Hematopoiesis: Mechanisms Driving Dominance of Stem Cell Clones. Blood 2020, 136, 1590-1598. [CrossRef]

107. Zink, F.; Stacey, S.N.; Norddahl, G.L.; Frigge, M.L.; Magnusson, O.T.; Jonsdottir, I.; Thorgeirsson, T.; Sigurdsson, A.; Gudjonsson, S.A.; Gudmundsson, J.; et al. Clonal hematopoiesis, with and without candidate driver mutations, is common in the elderly. Blood 2017, 130, 742-752. [CrossRef]

108. Bowman, R.L.; Busque, L.; Levine, R.L. Clonal Hematopoiesis and Evolution to Hematopoietic Malignancies. Cell Stem Cell 2018, 22, 157-170. [CrossRef]

109. Silver, A.J.; Jaiswal, S. Clonal hematopoiesis: Pre-cancer PLUS. Adv. Cancer Res. 2019, 141, 85-128. [CrossRef] [PubMed]

110. Chan, H.T.; Chin, Y.M.; Nakamura, Y.; Low, S.-K. Clonal Hematopoiesis in Liquid Biopsy: From Biological Noise to Valuable Clinical Implications. Cancers 2020, 12, 2277. [CrossRef]

111. Champion, K.M.; Gilbert, J.; Asimakopoulos, F.A.; Hinshelwood, S.; Green, A. Clonal haemopoiesis in normal elderly women: Implications for the myeloproliferative disorders and myelodysplastic syndromes. Br. J. Haematol. 1997, 97, 920-926. [CrossRef]

112. Fey, M.F.; Liechti-Gallati, S.; Von Rohr, A.; Borisch, B.; Theilkäs, L.; Schneider, V.; Oestreicher, M.; Nagel, S.; Ziemiecki, A.; Tobler, A. Clonality and X-inactivation patterns in hematopoietic cell populations detected by the highly informative M27 beta DNA probe. Blood 1994, 83, 931-938. [CrossRef]

113. Steensma, D.P. Clinical consequences of clonal hematopoiesis of indeterminate potential. Hematol. 2018, 2018, 264-269. [CrossRef]

114. Gibson, C.J.; Steensma, D.P. New Insights from Studies of Clonal Hematopoiesis. Clin. Cancer Res. 2018, 24, 4633-4642. [CrossRef] [PubMed] 
115. Genovese, G.; Kähler, A.K.; Handsaker, R.E.; Lindberg, J.; Rose, S.A.; Bakhoum, S.F.; Chambert, K.; Mick, E.; Neale, B.M.; Fromer, M.; et al. Clonal Hematopoiesis and Blood-Cancer Risk Inferred from Blood DNA Sequence. N. Engl. J. Med. 2014, 371, $2477-2487$. [CrossRef]

116. Jaiswal, S.; Fontanillas, P.; Flannick, J.; Manning, A.; Grauman, P.V.; Mar, B.G.; Lindsley, R.C.; Mermel, C.H.; Burtt, N.; Chavez, A.; et al. Age-Related Clonal Hematopoiesis Associated with Adverse Outcomes. N. Engl. J. Med. 2014, 371, 2488-2498. [CrossRef]

117. Liu, J.; Chen, X.; Wang, J.; Zhou, S.; Wang, C.; Ye, M.; Wang, X.; Song, Y.; Wang, Y.; Zhang, L.; et al. Biological background of the genomic variations of cf-DNA in healthy individuals. Ann. Oncol. 2019, 30, 464-470. [CrossRef] [PubMed]

118. Hu, E.; Ulrich, B.C.; Supplee, J.; Kuang, Y.; Lizotte, P.H.; Feeney, N.B.; Guibert, N.M.; Awad, M.M.; Wong, K.K.; Jänne, P.A.; et al. False-Positive Plasma Genotyping Due to Clonal Hematopoiesis. Clin. Cancer Res. 2018, 24, 4437-4443. [CrossRef] [PubMed]

119. Razavi, P.; Li, B.T.; Brown, D.N.; Jung, B.; Hubbell, E.; Shen, R.; Abida, W.; Juluru, K.; De Bruijn, I.; Hou, C.; et al. High-intensity sequencing reveals the sources of plasma circulating cell-free DNA variants. Nat. Med. 2019, 25, 1928-1937. [CrossRef] [PubMed]

120. Leighl, N.B.; Page, R.D.; Raymond, V.M.; Daniel, D.B.; Divers, S.G.; Reckamp, K.L.; Villalona-Calero, M.A.; Dix, D.; Odegaard, J.I.; Lanman, R.B.; et al. Clinical Utility of Comprehensive Cell-free DNA Analysis to Identify Genomic Biomarkers in Patients with Newly Diagnosed Metastatic Non-small Cell Lung Cancer. Clin. Cancer Res. 2019, 25, 4691-4700. [CrossRef]

121. Aggarwal, C.; Thompson, J.C.; Black, T.A.; Katz, S.I.; Fan, R.; Yee, S.S.; Chien, A.; Evans, T.L.; Bauml, J.M.; Alley, E.W.; et al. Clinical Implications of Plasma-Based Genotyping With the Delivery of Personalized Therapy in Metastatic Non-Small Cell Lung Cancer. JAMA Oncol. 2019, 5, 173-180. [CrossRef] [PubMed]

122. Rolfo, C.; Russo, A.; de Miguel-Pérez, D. Speeding tumor genotyping during the SARS-CoV-2 outbreak through liquid biopsy. Cancer 2020, 126, 4089-4091. [CrossRef] [PubMed]

123. Corcoran, R.B. Liquid biopsy versus tumor biopsy for clinical-trial recruitment. Nat. Med. 2020, 26, 1815-1816. [CrossRef] [PubMed] 